\title{
RELIGIUSITAS BHIMA DALAM TEKS DEWA RUCI
}

\author{
I Komang Widiana
}

Institut Hindu Dharma Negeri Denpasar

Email: komangwidiana@gmail.com

\begin{abstract}
:
The text of Dewa Ruci tells about the journey of the character Bhima in carrying out his swadarma as a student of Guru Drona to fulfill the task of finding tirtha amerta pawitra. From the story contained in Dewa Ruci's text, it has a different or contradictory phenomenon between Bhima-Drona and tirtha amerta pawitra. Thus a more in-depth study is needed of the religiosity of Bhima's figure on his journey in the literary work of Dewa Ruci from the point of view of Hindu Theology. Based on this description, in this study Bhima's character in the Dewa Ruci Text as the object of research, entitled "Religiosity Bhima in Dewa Ruci Text (Study of Hindu Theology). The results of the study obtained in this study, that the religiosity of Bhima's figure is reflected in Bhima's journey which is a process of self-control and surrender. In addition, the journey of Bhima's figure also reflects the holy journey which purifies him so that he is able to meet Hyang Dewa Ruci, in other words Bhima's journey is a form of thirtayatra. As well as other theological teachings found in Dewa Ruci's Text is the concept of pramana as a concept that supports living beings. By knowing this knowledge, it is hoped that Bhima as a depiction of humans can reach moxartham Jagadhitaya.
\end{abstract}

Keywords: Religiosity, Bhima, Dewa Ruci Text, Hindu Theology

\begin{abstract}
Abstrak:
Teks Dewa Ruci menceritakan tentang perjalanan tokoh Bhima dalam menjalankan swadarma-nya sebagai murid Guru Drona untuk menunaikan tugas mencari tirtha amerta pawitra. Dari cerita yang terdapat pada Teks Dewa Ruci ini memiliki fenomena yang berlainan atau kontradiktif antara BhimaDrona dengan tirtha amerta pawitra. Dengan demikian diperlukan suatu kajian lebih mendalam mengenai religiusitas tokoh Bhima pada perjalanannya dalam karya sastra Teks Dewa Ruci dari sudut pandang Teologi Hindu. Berdasarkan uraian tersebut maka dalam penelitian ini tokoh Bhima pada Teks Dewa Ruci sebagai objek penelitian, dengan judul "Religiusitas Bhima Dalam Teks Dewa Ruci (Kajian Teologi Hindu). Hasil penelitian yang diperoleh dalam penelitian ini, bahwa religiusitas tokoh Bhima tercermin dalam perjalanan Bhima yang merupakan proses pengendalian diri dan penyerahan diri. Selain itu perjalanan tokoh Bhima juga mencerminkan perjalanan suci yang menyucikan dirinya sehingga ia mampu untuk bertemu dengan Hyang Dewa Ruci, dengan kata lain perjalanan Bhima adalah suatu bentuk thirtayatra. Serta ajaran teologi lainnya yang terdapat pada Teks Dewa Ruci ialah adanya konsep pramana sebagai konsep yang menghidupi makhluk hidup. Dengan mengetahui pengetahuan ini diharapkan Bhima sebagai penggambaran manusia dapat mencapai moksartham jagadhitaya.
\end{abstract}

Kata kunci: Religiusitas, Bhima, Teks Dewa Ruci, Teologi Hindu.

\section{Pendahuluan}

Sebagai sumber rujukan dalam mempelajari Teologi Hindu, yang pertama dan utama adalah Veda dalam pengertian luas maupun dalam pengertian spesifik. Dalam pengertian spesifik sebagai berikut; Catur Veda yang tergolong sebagai sruti atau wahyu, smerti yang merupakan tafsir dari sruti, purana merupakan kisah atau cerita-cerita kuno dan silsilah pada zaman dahulu baik tentang raja-raja yang memerintah serta asal-asul dewa- 
dewa, sila ialah kebiasaan orang suci dan itihasa. Dijabarkan berdasarkan kronologinya menjadi empat bagian yang lebih mudah untuk dipelajari, hal ini terdapat dalam Menawadharmasastra II. 6-10. Keempat sumber itu antara lain; 1) Smerti ialah dharmasastra; 2) Sila yaitu tingkah laku yang baik dari orang-orang suci; 3) Acara yaitu tradisi atau dresta yang bernuansa Veda; dan 4) Atmanastuti yaitu kepuasan diri sendiri (Titib, 1996:29).

Melalui keempat sumber itu, Veda dijelaskan dan dijabarkan lebih terperinci menjadi puranapurana, upanisad, itihasa, dan lainnya. Itihasa ini merupakan kelompok kitab jenis epos, wiracarita atau cerita tentang kepahlawanan. Itihasa adalah sebuah epos yang menceritakan sejarah perkembangan raja-raja dan kerajaan Hindu dimasa silam. Kata Itihasa terdiri atas tiga bagian, yaitu iti-ha-asa. "Iti" dan " $h a$ " adalah kata tambahan yang "indeclinable" di dalam Bahasa Inggris, sedangakan kata "asa" adalah kata kerja "verb" di dalam Bahasa Inggris. Arti kata itihasa adalah ini sudah terjadi begitu (Titib, 2008: 7). Dengan kata lain, pemahaman akan arti kata itihasa membentuk konsep akan kebenaran pada kejadian yang diceritakan dalam epos itu begitulah nyatanya.

Itihasa terdiri dari dua jenis epos yakni Ramayana dan Mahābhārata. Dalam cerita Mahābhārata penokohan Bhima memiliki karakter yang teguh pendirian, pemberani, tidak kenal lelah dan senantiasa optimis menghadapi sesuatu. Sedangkan, Bhima dalam jagad wayang ditampilkan sebagai pahlawan yang dahsyat dengan perawakan tinggi besar dan gagah perkasa, memiliki watak yang lugas dan tegas, namun demikian Bhima juga ditampilkan sebagai tokoh yang terkesan kurang mengenal sopan santun (Wahyudi, 2012: 6). Selain itu tokoh Bhima dalam pemikiran dekontruksi yang sepihak, pemaknaannya lebih menonjolkan sisi bentuk dan sifat-sifat keraksasaannya dari pada dewa-nya.

Dalam Teks Dewa Ruci diceritakan bahwa
Sang Bhima mencari tirtha amerta pawitra yang menghidupkan dan mensucikan (amerta berarti diluar kematian; abadi; jiwa tertinggi; Tuhan; keindahan; sinar; segala sesuatu yang manis (Wijaya, 2007: 15)) ke dasar samudra. Dari cerita yang terdapat pada Teks Dewa Ruci ini memiliki fenomena yang berlainan atau kontradiktif antara Bhima-Drona dengan tirtha amerta pawitra. Dikatakan kontradiktif berkaitan dengan penggambaran dari watak tokoh dari Bhima dan Drona dengan kapasitas dari tirtha amerta pawitra yang bersifat suci. Pencitraan tokoh Bhima dalam dialog dengan kakaknya yakni Yudisthira dalam Suargarohanaparva menyebutkan Bhima bila makan selalu berlebihan dan tidak menghiraukan orang lain, serta memiliki sifat kearoganan apabila berhasil menyelesaikan suatu pekerjaan. Selain itu dalam cerita pertemuan Bhima dengan Hanoman dikatakan bahwa Bhima tidak terima dirinya diremehkan oleh seekor kera, sehingga ia marah dan menyombongkan dirinya bahwa ia adalah anak dari Dewa Vayu (Rajagopalachari, 2013: 176). Sehingga dapat dikatakan kontradiktif dengan penggambaran tokoh Bhima tersebut dengan tirtha amerta pawitra yang suci, dalam artian bukankah yang selayaknya mencari tirtha amerta pawitra ialah kakaknya yakni Yudisthira yang berpegang teguh dengan dharma. Namun dalam Teks Dewa Ruci, tokoh Bhima-lah diceritakan menjalankan tugas dari gurunya untuk mencari tirtha amerta pawitra.

Berdasarkan pada uraian latar belakang dan identifikasi masalah di atas, maka dapat dirumuskan permasalahan pokok sebagai berikut: Bagaimanakah religiusitas tokoh Bhima dari sudut pandang Teologi Hindu dalam Teks Dewa Ruci?

\section{Pembahasan}

\section{Religiusitas Tokoh Bhima dalam Teks Dewa Ruci}

Berbicara mengenai religiusitas akan mengantarkan pada sikap manusia dalam menjalankan agama, manusia bersikap menyerahkan diri kepada Tuhan, kepada dewadewa, kepada roh nenek moyang dan dapat dikatakan bahwa manusia dalam menyerahkan diri kepada kekuatan tinggi yang disembahnya (Koentjaraningrat 2009:297). Sehinggareligiusitas 
akan membicarakan usaha indvidu maupun suatu kelompok untuk mendekatkan dirinya padaTuhan Yang Maha Esa. Seperti halnya tokoh Bhima dalam perjalanannya memiliki nilai-nilai religi yang sangat dalam, yang merupakan usaha Bhima memenuhi kewajibannya.

Teks Dewa Ruci yang menggambarkan perjalanan Bhima ke samudra, menurut Mesi (wawancara pada tanggal 20 Januari 2018) sebagai suatu perjalanan sepiritual untuk menyucikan diri selain dalam hal menunaikan tugasnya sebagai murid dari Guru Drona. Berkaitan dengan perjalanan Bhima dikaitkan ke dalam kehidupan masyarakat Bali pada saat ini, terdapat upacara yang identik dengan upacara melasti atau mekiis yang bertujuan untuk penyucian dan nunas tirtha dari laut/samudra, danau, sungai dan sumber mata air ataupun jurang. Hal ini seperti yang disampaikan Mesi, sebagai berikut:

\section{Sang Bhima memargi, ngemargiang swadharma wantah nyuciang raga, sekadi di bali ngemargiang upacara mekiis nunas penyucian ring genah toya medal, ring pasih, ring danu utawi ring tepining jurang. Pemargin Bhima wantah sekadi metirthayatra.}

Terjemahannya:

Sang Bhima berjalan, menjalankan kewajibannya untuk menyucikan diri, seperti di Bali melaksanakan upacara mekiis uantuk memohon kesucian di tempat sumber mata air, di laut, di danu dan di tepi jurang. Perjalanan Bhima ialah perjalanan suci.

Bahkan Putra (wawancara pada tanggal 24 Januari 2018) menegaskan pendapat dari Mesi sebagai berikut:

"disetiap perjalanan Bhima, terdapat perekembangan rasa kepercayaan yang tumbuh untuk mencari kebenaran yang paling utama. Kenapa seperti itu? Sebab perjalanan Bhima adalah perjalanan yang hanya dapat dilakukan oleh dirinya seorang, perjalanan yang suci. Bisa disebut sebagai sebuah tirthayatra spiritual untuk Bhima".
Berdasarkan hasil wawancara tersebut dapat ditarik kesimpulan bahwa perjalanan yang dilakukan oleh Bhima selain sebagai menunaikan tugas yang diberikan oleh gurunya kepada dirinya, juga sebagai perjalanan yang meningkatkan religiusitasnya dalam kehidupan di dunia ini guna dapat mendekatkan diri kehadapan Tuhan Yang Maha Esa. Melalui perjalanan yang dilakukan Bhima tentunya terjadi peningkatan spiritualitas dalam diri Bhima, hingga ia sampai di laut yang menjadi tujuannya. Rg Veda menyebutkan bahwa air adalah sarana untuk menyucikan diri, seperti yang terdapat pada kutipan mantra Rg Veda II. 35. 3, berikut:

sam anya yanty upa yanty anyah Samanam urvam nadyah prnnanti

Tam u sucim sucayo didivansam Apam napatam paritasthur apah

Terjemahannya:

Sejumlah besar air, bersama dengan yang lainnya berkumpul menjadi sungai yang mengalir bersama-sama menuju kepenampungan (laut/samudra). Air yang murni (sucim), baik dari mata air maupun dari laut, mempunyai kekuatan yang menyucikan (Titib, 1998: 245).

Dengan adanya penyucian diri serta kemantapan dalam keyakinan di dalam diri Bhima, menyebabkan keberhasilan disetiap langkahlangkah yang diambil oleh Bhima. Dengan berpegang teguh dengan dharma dan swadharma yang dilakukannya, Bhima kembali memperkuat keyakinan yang dimilikinya sehingga ia dapat bertemu dengan Hyang Dewa Ruci. Hal ini pula di pertegas dalam Rg Veda X. 17. 10 sebagai berikut: Apo asman matarah sundhayantu Ghrtena no ghrtapvah punantu, Visvam hi ripram pravahanti devir Ud id abhyah sucir a puta emi.

Terjemahanya:

Semogalah air suci ini menyucikan kami bercahaya gemerlapan. Semogalah 
pembersih ini membersihkan dengan air suci. Semoga air suci ini mengusir segala kecemaran. Sungguh, kami bangkit memperoleh kesucian dari padanya (Titib, 1998: 247 dan 248).

Termuat juga dalam Rg Veda 65.3 sebagai berikut:

Ta bhuripasav-arrtasa setu

Duratyetu repave martyaya

Rtasya mitra-varuna patha vam

Apo na nava durita tarelma

Terjemahannya:

Mitra dan Varuna yang memiliki banyak jerat adalah para pengawas kebohongan. Mereka tidak dapat dicapai oleh orang yang tidak memiliki keyakinan. Ya, Mitra dan Varuna, semoga kami melintas lautan kehidupan yang kacau dengan terangnya kebenaran dan kebenaran yang diperlihatkan oleh-Mu, sebagaimana seorang peziarah melintasi sungai dengansebuah perahu (Titib, 1996: 310).

Melalui keyakinan yang terdapat dihati Bhima, Bhima berhasil selamat dari arus gelombang samudra yang bergulung-gulung. Samudra yang diseberangi oleh Bhima jika ditafsirkan berdasarkan teori hermeneutika menuntun pada lautan yang lebih luas bukan hanya terbatas pada lautan yang berisi air. Berdasarkan tanda-tanda yang melekat pada tokoh Bhima, yang tentunya suatu penggambaran yang imajinatif bahwa seorang manusia dapat berenang sangat lama di tengah lautan yang bergelombang. Namun apabila di tafsirkan maka akan didapatkan artian yang lebih masuk akal yakni lautan kehidupan ini. Lautan kehidupan dengan gelombang yang tidak menentu dengan berbagai lika-likunya yang menjerat manusia. Religiusitas tokoh Bhima dalam Teks Dewa Ruci dapat lebih jelas diuraikan lebih terperinci sebagai berikut:

\section{A. Pengendalian Diri Tokoh Bhima dalam Teks Dewa Ruci}

Pengendalian diri adalah kemampuan dalam mengendalikan indriya dan mengontrol gerak pikirannya, baik yang berkaitan dengan nafsu, keinginan dan selera (kama).

Dalam pengendalian diri, pikiranlah yang menentukan orang mendapatkan celaka atau selamat dalam hidup ini. Oleh karena pikiran, juga seseorang mendapatkan sorga, neraka dan sebagainya. Pikiranlah yang menyebabkan Sang Diri menikmati sorga, jatuh ke neraka, menyebabkan menjadi binatang, menyebabkan orang mendapatkan kelepasan (Gunadha, 2013: 121)

Berdasarkan uraian di atas, yang paling pokok dalam pengendalian diri adalah pikiran. Dengan terkontrolnya pikiran maka seseorang akan diarahkan kedalam jalan yang benar hingga ia mencapai kebahagian baik di dalam dunia ini maupun di kehidupannya nanti. Dengan terkontrolnya pikiran akan mengarhkan manusia untuk mencapai suatu kelepasan. Pikiran adalah pusat dari seluruh indria yang ada dalam tubuh manusia sehingga disebut dengan raja indria. Karena berpikir juga merupakan bagian dari perbuatan yang dilakukan oleh pikiran, berkata juga merupakan perbuatan yang dilakukan oleh perkataan, berjalan dan segala aktifitas gerak adalah suatu perbuatan yang dilakukan oleh tubuh. Singkatnya semua terpusat oleh pikiran. Mengingat semua perkataan dan perbuatan yang dilakukan oleh manusia berasal dari pikiran, yang apabila tidak terkontrol akan memunculkan sifat pikiran yang liar, tidak pernah diam, penuh kegelisahan, penuh keinginan (Gunadha, 2013: 117).

Pengendalian diri yang dilakukan oleh Bhima dapat diuraikan dari pengendalian pikiran Bhima yang selalu fokus dalam menunaikan tugas yang diembannya. Hal ini tentunya sangatlah sulit dilakukan apabila tidak adanya karakter taat yang dimiliki Bhima. Waluapun keragu- 
raguan menghampiri dirinya, namun Bhima mampu menenangkan pikirannya sehingga ia dapat melanjutkan perjalanannya. Seperti yang dipaparkan pada kutipan berikut:

"Lumebu sireng samudra, wiraganira laghawa, banyu sumaput ing wetis, saking tur melek ing angga, sumarambhahtekenggulu, arus sumembur ing muka, minggek sangsaja manengah, kanut de ning alum adres" (Dewa Ruci, pupuh I pada 28).

Terjemahannya:

Masuk kedalam laut dengan hati yang hening dan ringan, air memenuhi betis, dari lutut meluas sampai badan, menyebur muka, berpaling menyelam ketengah, hanyut dibawa harus yang kuat (Tim Penyusun, 2008: 10).

Kutipan di atas, menyebutkan Bhima dengan hati yang hening dan ringan memasuki air laut yang memiliki arus yang kuat. Ketenangan hati tidak akan didapat tanpa adanya penenangan pikiran. Melepasakan pikiran dari ikatan keragu-raguan dan beban serta kegelisan akan menenangkan pikiran. Dengan tidak adanya ikatan-iktan yang mebebani pikiran akan tercapai ketenangan hati dan kelapangan dalam melaksanakan kewajiban. Sehingga melalui ketenangan hati akan diperoleh suatu kebahagian dikehidupan ini. Hal ini sangat relevan dengan apa yang disebutkan dalam kitab Sarasamuccaya sloka 81 , sebagai berikut:

$D u r a g a m b a h u d a g h a m i$ prarthanasamsayatmakam, manah suniyatam yasya sukhi pretya veha ca. nihan ta karma nikang manah, bhnanta lungha svabhawanya, akweh mangenangenya, dadi prathana, dadi sangsaya, pinakawaknya, hana pwa wwang ikang wenang humeret manah, sira tika menggeh amanggih sukha, mangke ring paraloka kabeh.

Terjemahannya:

Keadaan pikiran itu, demikianlah tidak berkententuan jalannya, anyak yang dicitacitakannya, terkadang penuh kesangsian, demikianlah kenyataannya: jika ada orang dapat mengendalikan pikirannya, pasti orang itu beroleh kebahagian, baik sekarang maupun di dunia lain (Kajeng, 1997: 70).

Kebahagian didapatkan melalui pengendalian diri dengan mengontrol keinginan dan berteman dengan pikiran. Dengan demikian pikiran akan berjalan di jalan yang lurus, sehingga sang diri dapat berjalan dijalan dharma. Pikiran dapat dikendalikan dengan kebijaksanaan sehingga semua keinginan yang berkaitan dengan indriaindria pada badan dapat terkontrol dengan baik. Selain hal tersebut, dalam pengendalian diri diperlukan penguasaan diri dan mengenal diri sendiri dengan baik. Penguasaan diri dalam hal ini adalah lembut akan diri sendiri, belakangan di zaman modern ini manusia terlalu keras akan dirinya dengan berabagai keinginan yang membebani dirinya sendiri. Hal ini menjadi penting, dikarenakan dangan banyak keinginan akan sangat susah untuk dipenuhi. Dengan cara memfokuskan pada satu keinginan dengan berlandaskan dharma dan swadharma maka akan mengurangi beban yang dialami oleh tubuh. Hal ini diperlihatkan oleh Bhima dalam melaksanakan tugasnya, tentunya merupakan pengendalian diri yang dilakukan Bhima terhadap dirinya. Seperti yang diketahui Bhima adalah tokoh yang tidak sabaran, namun pada Teks Dewa Ruci Bhima disebutkan dengan lembut dan sabar mendengarkan apa yang diwejangkan oleh Hyang Dewa Ruci, seperti yang terungkap dalam kutipan berikut:

"Tuhu Manggih gatinira Bhaywa atmaja kummel, den ta wruh basa, kang ginseng I jro, inget warah sang kaka tuhu ning katha asoka Wrekodara mararem.

Somnya wuwus Wrekodara mandra malon, tuhun hulun endi kahinanku ring rat, sopanangku lumampah tekeng jaladhi, cawuh Drona purohitangku mangutus

Towin hulun sanyasa wruh I jatinta, yen atuhu yen arusit yan yen asadhu, den jati ning duhung tan kawara, wacananta tan kawara, wacananta den apadang tanpa 
sing (?) ingan.

Ling Bhimasena tusta Hyang Janardana, denira ayun weruh ing kasatwikan, karma kinon amanjinga garbha denta, tusta saha guyu Baywatmaja jenger" (Dewa Ruci, Pupuh IV pada 14-17).

Terjemahannya:

Bhima menjadi lunak hatinya ketika ia tahu tujuannya diketahui dan sang resi tahu apa yang tersimpan dalam hati, teringatlah ia akan nasehat kakaknya yang merupakan kata-kata yang benar, Sang Bhima menjadi sedih dan terdiam.

Lembut kata-kata sang Bhima halus dan pelan, "benar aku di dunia ini amat bodoh sebab aku datang ke laut ini, guruku Drona yang tidak bijaksana mengutus hamba"

Dan hamba agaknya mengetahui siapa sesungguhnya Engkau, Engkaulah kebenaran, Engkaulah rahasia, Engkaulah kebajikan, seperti halnya keris tanpa sarung, demikianlah hendaknya katakatanya jelas tanpa dibatas-batasi (?).

Demikian kata sang Bhima, senang sang Dewa Ruci, Karena sang Bhima mau mengetahui ujaran kebenaran. Maka disuruh: "masukilah garbhaku olehmu" senang dan tertawa sang Bhima terpesona. (Tim Penyusun, 2008: 20 dan 21).

Berdasarkan apa yang terdapat pada kutipan di atas, dapat diketahui bahwa Bhima meiliki kepribadian yang emosional. Sekejap Bhima bisa dipenuhi rasa yang taat, sekejap bahagia, sekejap lagi ia merasakan sedih dan seketika juga ia merasakan kebahagian. Hal ini terlihat ketika Bhima ingat akan kata-kata dari kakaknya ia merasakan kesedihan namun ketika ia mendengarkan apa yang diwejangkan oleh Hyang Dewa Ruci, Bhima tertawa. Dengan kata lain, Bhima tidak terikat dengan suka maupun duka dalam kehidupan ini. Perjalanan yang dilakukan Bhima adalah perjalanan yang membentuk diri Bhima, membentuk kepribadian Bhima. Seperti ungkapan pengalaman adalah guru yang utama, begitupula Bhima belajar dari pengalamanya.
Perjalanan yang dilakukan Bhima juga merupakan tapa yang dilakukan Bhima dalam kehidupannya. Tapa dalam perenungannya untuk mengetahui kebenaran sejati. Hal ini seperti kutipan berikut:

"Sing bhaya tan hana ketang de sang Ardhanareswari, anging dharma kang ingista, sampurna ning uripira, denirayun wruheng dharma, amalar dibya kapatin, karananira arepta, parastra eng dalem pasir" (Dewa Ruci, pupuh I pada 27).

Terjemahannya:

Apapun bahaya tidak dihiraukan, oleh sang Bhima, hanya dharma yang diperhatikannya. Ia menghendaki kesempurnaan hidup, karena itu ia ingin mengetahui dharma. Ingin mati terhormat, karena itu menghendaki mati di dalamlaut (Tim Penyusun, 2008: 10).

Hal ini sangatlah menunjukan bahwa perjalanan yang dilakukan Bhima selain untuk menunaikan tugasnya ia menginginkan untuk mengetahui kesempurnaan hidup. Dengan menjalankan tugas yang diberikan oleh gurunya, Bhima melakukan daksina (penghormatan) kepada gurunya. Dengan melakukan perjalanan tersebut Bhima akan menemukan jawaban yang dicarinya. Hal ini sangat relevan dengan yang terdapat dalam Kitab Yajur Veda XIX. 30 sebagai berikut:

\section{Vretanam diksam apnoti \\ Diksaya-apnoti daksinam daksina sraddham apnoti srddaya satyam apyate.}

Terjemahannya:

Dengan menjalankan brata, seseorang mencapai diksa (penyucian diri). Dengan diksa seseorang mencapai daksina (penghormatan). Denga daksina seseorang mencapai sraddha (kepeksina seseorang mencapai sraddha (kepercayaan/ keyakinan) dan melalui sraddha seeorang menyadari kebenaran sejati/tuhan yang Maha agung (Titib, 1996: 448). 
Pengendalian diri yang terdapat pada tokoh Bhima juga terlihat ketika Bhima berada di dalam lautan, seperti dalam kutipan berikut:

"Sangsara lampah nararya, dening ombak agulungan, anglangi sira kapesan, kanut de ning alun ageng, angemu loh ing udadhi, pegangulah kedal-kedal, angambang lwir sawa kanut, kadi jong banawa karem.

Angelih asah tang nala, deni dalemoing arnawa, atahen sira kapesan, gupe angga kelem sampun, anging kang ingisti manah,amriha dileya kapatin, anging dharmaji kang kesti, tan karaketan ing urip" (Dewa Ruci, pupuh I pada 29 dan $30)$.

Terjemahannya:

Sengsara perjalanan sang Bhima, karena ombak yang bergulung-gulung, ia berenang kelelahan, dihanyutkan oleh alum besar, menahan air dimulut, susah bergerak menggelepar-gelepar, mengambang seperti mayat yang hanyut, seperti perahu yang karam.

Letih gelisah hatinya, karena dalamnya laut, bertahan ia dalam kelelahan, lemas badannya lalu tenggelam, namun yang diharap dalam hati, mengingini mati terhormat, hanya dharma yang diingin, tidak terikat oleh kehidupan (Tim Penyusun, 2008: 11).

Berdasarkan kutipan di atas, dapat diuraikan bahwa diantara kondisi Bhima yang tidak diuntungkan dalam kondisinya yang kelelahan, letih dan berada pada di kedalaman samudra. Serta dengan kondisi gelombang yang menghantamnya, Bhima tidak kehilangan arah tetap meyakini keyakinannya. Bhima tetap meyakini tentang jalan dharma yang ia pegang. Hal tersebut dapat Bhima lakukan apabila ia telah mengendalikan dirinya, meneguhkan hatinya dalam melaksanakan tugas yang diberikan gurunya. Hingga Bhima mampu untuk melepaskan ikatananya terhadap kehidupan ini, untuk mendapatkan pengetahuan yang tentang kesempurnaan hidup yang berarti tentang kebenaran yang paling utama. Apa yang dialami Bhima sangat relevan dengan yang disebutkan dalam Bhagawadgita bab II sloka 37 berikut ini:

\section{Srutivipratipanna te \\ Yada stasyati niscaya, \\ Samadaw acala buddhis \\ Tada yogam awapsyasi.}

Terjemahannya:

Bila pikiranmu diumbang-ambingkan oleh perbedaan-perbedaan pendapat, tidak berubah-ubah dan jiwa tetap teguh (Samadhi), maka engkau akan mencapai yoga kesadaran suci (Sudharta, 2014: 177)

Dengan temuan pada pembahasan sebelumnya bahwa Bhima merupakan simbol dari diri manusia dan samudra/lautan yang diseberangi oleh Bhima sebagai lautan kehidupan. Maka Bhima tidak diumbang-ambingkan oleh pikiran-pikiran yang lain di luar dirinya. Tidak terpengaruh oleh pendapat orang lain, dan teguh untuk melaksanakan tugas dari gurunya sebagai penghormatan kepada gurunya. Dengan keteguhan yang dimiliki Bhima, yang menurut Bhagawadgita keteguhan adalah semadhi maka Bhima akan mencapai yoga kesadaran suci. Sehingga keteguhan hati yang dimiliki Bhima merupakan bagian dari pengendalian diri yang dilakukan Bhima, sehingga ia mampu untuk bertemu dengan Hyang Dewa Ruci sehingga dapat mendengarkan wejanga-wejangan yang paling utama.

Menurut Sugata (wawancara pada tanggal 15 Januari 2018) mengungkapkan bahwa: Kondisi perut yang ditekan ke dalam, pada saat pernafasan bermanfaat menyerap energi dan sebagai sarana pengendalian diri yang disebut dengan bandha dalam yoga. Kondisi ini diikuti dengan mengkerucutkan anus ke dalam, sehingga energi yang telah diserap tidak akan keluar dari badan. Kondisi dari bandha dalam yoga jika dikaitkan dengan tokoh Bhima terdapat kemiripan dengan deskripsi yang dari nama lain dari Bhima yaitu Werkudara.

Nama Werkudara memiliki arti berperut 
serigala. Werkudara berasal dari Bahasa Sansekerta yakni Vrkodara, berasal dari kata "Vrka" yang berarti anjing dan "udara" artinya perut. Berperut seperti perut anjing (kecil) dan dadanya lebar, menggambarkan Bhima sebagai teladan dalam ketegaran, ketegasan, dan kerja keras serta berani mengambil resiko. Dari pengertian tersebut, terdapat kesamaan dengan posisi bandha dalam yoga dengan penggambaran tokoh Bhima dari nama Werkudara. Dengan demikian, Bhima disetiap melakukan kehidupannya melakukan pengendalian diri dengan penuh keteguhan.

\section{B. Penyerahan Diri Tokoh Bhima dalam Teks Dewa Ruci}

Manusia sebagai makhluk yang ber-Tuhan, selalu berusaha untuk mendekatkan dirinya kepada yang disembahnya yakni Tuhan Yang Maha Esa. Manusia yang memiliki keyakinan kepada Tuhan Yang Maha Esa akan selalu berserah diri dan beruasaha yang terbaik dalam kehidupan ini. Banyak factor yang menyebabkan manusia untuk menyerahkan diri kepada kekuatan yang lebih tinggi yang diyakini. Menyerahkan diri yang diacu dalam tulisan ini bukan akibat dari ketakutan dan ketidakberdayaan, melainkan dikarenakan atas keyakinan yang terdapat pada dirinya.

Bhima yang merupakan salah satu dari lima Pandawa mendapatkan tugas dari gurunya. Bhima mempercayai gurunya sehingga ia bisa mengabaikan saudaranya dan Ibunya. Dengan kepercayaan itu, Bhima menyerahkan dirinya kepada gurunya, yang mana Bhima mengharapkan diajarkan tentang kebenaran yang paling utamanya dari grunya. Sehingga dengan penyerahan diri ini, Bhima menerima tugas yang diberikan walaupun tugas yang diberikatan itu penuh bahaya dan menyengsarakan diri Bhima, seperti yang disebutkan dalam kutipan berikut:

"Gatya lampahi nararya, pangutusing Dang Hyang Drona, ameta toya pawitra, suci mawenang... lali sireng pa wwang sanak, iba tan ketang denira, lagwa sireng antaka, tan jrih durgama ning pasir" (Dewa Ruci, pupuh I pada 1).
Terjemahannya:

Cepat langkah sang raja putra, sebagai utusan Dang Hyang Drona, untuk mencari air suci, suci jernih, lupa ia pada sanak saudara, ibunya tidak diharaukannya, ia iklas untuk mati, tidak takut pada bahaya laut (Tim Penyusun, 2008: 1).

Dengan kepercayaan pada gurunya, Bhima berjalan dan menjalankan tugasnya. Walaupun ia mengabaikan ibunya, namun Bhima pada saat itu dalam posisi sebagai murid dari Drona sehingga apa yang ditugaskan oleh gurunya menjadi swadharma-nya Bhima. Hal ini relevan dengan petikan Taittiriya Upanisad 1.11 berikut:

matradevo bhava pitrdevobhava

acaryadevo bhava atithidevo bhava

Terjemahannya:

Seorang ibu adalah dewa, seorang bapak adalah dewa, seorang guru adalah juga dewa dan para tamu pun adalah dewa (Titib, 1996: 74).

Berdasarkan petikan pada Taittiriya Upanisad di atas, yang mana Bhima berkedudukan sebagai murid yang dalam masa pengejaran maka Bhima manganggap bahwa gurunya sebagai dewa, sehingga ia mempercayakan hidupnya kepada gurunya. Berbeda kedudukannya apabila Bhima tidaka dalam masa berguru tentunya Bhima akan mendengarkan apa yang dikatakan oleh Ibunya. Sehingga dalam dilemma itu, Bhima memutuskan untuk menyerahkan dirinya kepada gurunya yang secara tidak langsung pasrah kepada Tuhan Yang Maha Esa.

Penyerahan diri Bhima dapat pula dilihat ketika Bhima telah sampai di tepi pantai, seperti dalam kutipan berikut:

"Sing bhaya tan hana ketang de sang Ardhanareswari, angingdharmakangingista, sampurna ning uripira, denirayun wruheng dharma, amalar dibya kapatin, karananira arepta, parastra eng dalem pasir" (Dewa Ruci, Pupuh I pada 27). 
Terjemahannya:

Apapun bahaya tidak dihiraukan, oleh sang Bhima, hanya dharma yang diperhatikannya. Ia menghendaki kesempurnaan hidup, karena itu ia ingin mengetahui dharma. Ingin mati terhormat, karena itu menghendaki mati di dalam laut (Tim Penyusun, 2008: 10).

Dari kutipan di atas, dapat diketahui bahwa Bhima menyerahkan dirinya kepada penguasa lautan dengan kehendaknya untuk mati di laut apabila ia tidak berhasil menemukan apa yang menjadi tugasnya. Dengan penyerahan diri ini, secara tidak langsung Bhima menyerahkan dirinya untuk dipeluk oleh lautan yang dikuasai oleh Hyang Varuna sebagai personifikasi Tuhan Yang Maha Esa sebagai penguasa lautan. Hal ini sesuai dengan petikan mantra Rg Veda X. 32. 6 berikut ini:

Nidhiyamanam apagughvhamapsu

Pra me devanam vratapa uvaca

Indro viddham anu hi tva cacaksa

Tenaham agne anusista agam

Terjemahannya:

Dari Engkau yang tersembunyi di dalam air, yang mempertahankan hukum-hukum dewa-dewa memberikan kami. Indra, yang mengetahui, menyaksikan dan menunjukan kepada Engkau. Berkat pengajarannya, ya Agni, kami lahir (Titib, 1998: 249).

\section{Religiusitas Tokoh Bhima dari Sudut Pandang Teologi Hindu dalam Teks Dewa Ruci}

Berbicara mengenai sudut pandang teologi Hindu yang terdapat pada tokoh Bhima dalam Teks Dewa Ruci diuraikan terlebih dahulu mengenai pengertian teologi, teologi berasal dari kata theos yang artinya Tuhan dan logos yang artinya ilmu atau pengetahuan. Dengan demikian teologi adalah pengetahuan tentang Tuhan. Ontologi dari teologi adalah Tuhan, dengan demikian secara ontologis pembahasaan teologi berpusat pada konsep tentang Tuhan (Donder, 2006: 4\&11)
Berdasarkan pengertian teologi di atas, dapat diuraikan lebih terperinci religiusitas tokoh Bhima dari sudut pandang Teologi Hindu dalam Teks Dewa Ruci sebagai berikut:

\section{A. Konsep Pramana dalam Teks Dewa Ruci}

Atma atau atman dalam kamus Besar Bahasa Indonesia diartikan sebagai jiwa, nyawa atau roh. Ketiga kata tersebut memiliki maksud yang sama yakni menujuk kepada kehidupan. Gunaddha (2013: 87) mengatakan bahwa jiwa adalah keberadaan yang memberi hidup yang disebut pula sebagai jiwatman. Sedangkan dalam Upanisad, kata Atman berasal dari kata prana (nafas) dan atman (asas hidup). Sedangkan pada Teks Dewa $R u c i$ asas yang memberi kehidupan yang dikenal dengan jiwa disebut dengan pramana, seperti yang disebutkan dalam kutipan berikut;

Sang pawanatmaja muwus, atakwan sang Jineresi. Sawulatku arja kila, sawang putraputri kara... lengit leyep tiningalan, tan iku tiningalan, iku urip ing sarira.

Pramana iku aranya, tan milu suka dukung rat, tanpa mangan tanpa turu, tan milu lara mwang lapa, yan apisah lawan raga, awak drawa tanpa sesa, ring ulah ulahing angga, kawisesa ing pramana (Dewa Ruci, pupuh V pada 12 dan 13).

Terjemahannya:

Sang Bhima berkata, bertanya kepada sang Dewa Resi, apa yang kulihat indah bersinar, seperti boneka bercahaya,..., samar-samar terlihat, "bukan itu yang terlihat, itu adalah jiwanya badan."

Pramana (jiwa) namanya itu, tidak ikut mengalami suka duka dunia, tanpa makan, tanpa tidur, tidak ikut sakit dan lapar, bila terpisah dengan badan, badan hancur tanpa sisa, apa yang dilakukan oleh badan dikuasai oleh pramana (Tim Penyusun, 2008: 29).

Berdasarkan kutipan di atas, disebutkan pramana adalah jiwanya badan, yang bersinar dan bercahaya. Pramana ini tidak dipengaruhi oleh rasa lapar dan haus sehingga pramana tanpa makan dan minum. Pramana jga memilki sifat 
tidak mengalami suka dan dukanya dunia. Hal ini relevan dengan yang disebutkan pada Chandogya Upanisad VIII. 7. 1, sebagai berikut:

Ya atma apahata patma vijaro vimrtyur visako vijighatso 'pipasah satya kamah, satya samkalpah, so 'nvesttavtah, so vijijnasitavyah sa sarvams ca lokan apnoti sarvams ca Kaman. Yas tam atmanam anuvidya vijanati. Iti ha prajapatir uvaca.

Terjemahannya:

Atma bebas dari kejahatan, bebas dari tua, bebas dari kematian, bebas dari kesedihan, bebas dari lapas dan haus. Yang keinginannya adalah kebenaran, yang pikirannya adalah kebenaran. Ia dapat dicari, padanya seseorang dapat berkeinginan untuk memahaminya. Seorang yang telah menemukannya dan memahaminya ia mendapatkan dunia,

seluruhnya. Demikianlah Prajapati berkata (Sura dalam Gunadha, 2013: 92).

Selain hal tersebut, pada Teks Dewa Ruci disebutkan lebih lanjut tentang pramana dalam wejanga-wejangan Hyang Dewa Ruci kepada Bhima sebagai berikut:

To win urip ing pramana, sinung urip de ning suksma, inguripan pada suksma, snandanga ken ing sira, saksat simbar munggwing kaywan, annane ana ri kita, tan milu tusta bancana, yan mati milu kalusya.

Ilang suksma ning sarira, urip ing suksma kapanggih, kadi gilahara-hara, lwir rasa aneng kamumu imbuh leng leng tingalira de ning senen marakata, sri Wrescana mawarah, anta urip ing pramana (Dewa Ruci, pupuh V pada 14 dan 15).

Terjemahannya:

Adapun uripnya pramana, diberi uripoleh dia yang suksma (halus) yang memberi urip sama-sama suksma, dilekatkan pada dirimu, seperti simbar kayu, adanya berada pada dirimu, tidak ikut senang ataupun susah, bila mati ikut pergi.
Hilang suksmanya badan, uripnya suksma dijumpai, bersinar seperti gelas (?) seperti air pada talas, bertambah kagumnya pada apa yang dilihatnya karena sinarnya yang bersinar. Sang Dewa Ruci mengajarkan inti dari uripnya pramana (Tim Penyusun, 2008: 29).

Demikianlah apa yang diajarkan Hyang Dewa Ruci kepada Bhima mengenai pramana . Pramana merupakan asas penyebab dari kehidupan makhluk hidup. Dialah yang menyebabkan manusia mampu bergerak dan berkarya. Pramana menjadi sumber dari akal, rasa, dan indria. Serta dari pramana terdapat wadah yang berupa badan. Bilamana pramana meninggalkan badan maka yang terjadi adalah kematian untuk badan, sedangkan pramana akan kembali kepada suksma. Ia akan tetap bersinar, walaupun telah terikat oleh badan yang telah ia tinggali. Seperti halnya yang disebutkan pada Chandogya Upanisad VI. 11. 3 sebagai berikut:

Jivatetam vava kiledam mriyate na jivo mriyata iti say a eso, nima aitad at mayam idam sarvam tat styam sa atma tat tvam asi

Terjemahannya:

Sesungguhnya tubuh ini akan mati, bila ditinggalkan oleh atman dan atman yang hidup tidaklah bisa mati. Itu yang merupakan sari paling halus dari alam semesta ini. Itulah yang benar. Itulah atman, Engkau adalah itu.

Relevan juga dengan apa yang disebutkan dalam Bhisma Parwa sebagai berikut:

Kadi rupa Sang Hyang Aditya an prakasan iking sarwa loka, Mangkana ta Sang Hyang Atma an prakasanaken iking sarira, sira marganyam wenang maprawatti

Terjemahannya:

Sebagai rupanya Sang Hyang Aditya menerangi dunia, demikianlah atman menerangi badan, Dia-lah yang menyebabkan kita dapatberbuat.

Terdapat persamaan antara penyebutan yang terdapat pada Chandogya Upanisad dan Bhisma 
Parwa mengenai ciri-cari atman dengan apa yang disebutkan dalam Teks Dewa Ruci mengenai ciriciri pramana. Selanjutnya Hyang Dewa Ruci juga menyebutkan bahwa pramana tidak laki maupun perempuan seperti dalam kutipan berikut:

Ilang rupanikang jagat, salwir ning reka tan hana tinon aken urip ira, de sang parama Buddhengrat, winarnaken nira wahya, sawang putra-putran danta, samali muka gumana tan kakung sira tan istri (Dewa Ruci, pupuh $\mathrm{V}$ pada 10).

Terjemahannya:

Hilang wujud dunia ini, segala wujud penjelmaan tidak ada lagi, maka diperlihatkanlah jiwanya (sang Bhima) oleh sang Dewa Ruci yang mulia, dalam wujud nyata, seperti boneka gading dengan wajah kotor (?) tidak laki tidak perempuan (Tim Penyusun, 2008: 28).

Hyang Dewa Ruci dengan segala kemahakuasaan-Nya memperlihatkan Bhima jiwa yang menjadi asas kehidupan Bhima. Jiwa digambarkan sebagai boneka gading yang tidak berjenis kelamin laki-laki maupun perempuan. Apa yang disebutkan pada Teks Dewa Ruci mengenai sifat dari pramana memilki kesamaan dengan sifat atman seperti yang disebutkan pada Svetasvatara Upanisad V. 10, sebagai berikut:

Naiva stri na puman esa na caivayam napumsakah yad yac chariram adatte tena sa raksyate.

Terjemahannya:

Atman tidak perempuan, pun pula tidak bersifat pria. Ini juga tidak bersifat banci. Atman dapat mengambil sesuatu wujud makhluk yang bagaimana pun sebagai tubuhNya (Gunaddha, 2013: 94).
Tentang pembahasan pramana, Hyang Dewa Ruci menyebutkan lebih terperinci bagaimana pramana berada pada badan namun juga tidak terletak pada badan. Pramana melingkupi seluruh makhluk hidup tapi secara bersamaan ia tidak melingkupi segalanya. Pramana juga memiliki sifat tidak dapat disentuh, tanpa wujud bila dipikirkan. Seperti yang disebutkan dalam kutipan berikut ini:

Aneng kita dudu kita, aneng waneh dadu waneh, Salwir ing gumelar ing rat, pada sinandang anira, warna-warna yan warnanen, apan ora tinonaken, tanpa rupa idepira, wekas ing suksma wisesa.

Towin warna aneng sira, kadi warna ning sinambah, urip tan ringurip sira, amanusa tanpa warna, tan kagarbha teka ri heng, tan kawengku ing sarira, duranira tanpa warah, aparek tanpa gasikan (Dewa ruci, pupuh V pada 16 dan 17).

Terjemahannya:

Berada pada dirimu tetapi juga tidak pada dirimu, pada yang lain namun juga tidak pada yang lain, segala yang ada di dunia, sama-sama dilekati olehnya, bermacammacam bila dibayangkan, karena tidak dapat dilihat tanpa wujud bila dipikirkan, halusnya halus mahakuasa.

Adapun wujudnya ada padamu adalah wujud sesuai dengan yang engkau sembah, ia adalah urip yang tidak diuripi, bukan manusia tanpa wujud, tanpa ruang datang ke dalam ruang, tak terkungkung dalam badan, jauhnya tidak dapat diceritakan dekat namun tidak dapat disentuh (Tim penyusun, 2008: 30).

Berdasarkan kutipan di atas, dapat diketahui bahwa pramana memiliki wujud sesuai dengan apa yang disembah, dengan kata lain terbentuk 
dangan daya akal manusia namun bukan itu wujud aslinya akibat dari pikiran manusia yang terbatas. Pramana berasal dari tempat yang tidak dapat dijangkau oleh akal daya manusia namun ia sangat dekat dengan manusia. Ialah menempati badan ini bagaikan tempat bermain dan menghidupi badan manusia. Seperti yang disebutkan pada petikan mantra Rg Veda I. 91. 13, berikut ini:

Soma rarandhi no hrdhi gavo na

Yavasesav a, marya iva sva okye.

Terjemahannya:

Tuhan Yang Maha Pengasih, semoga Engkau berkenan bersthana pada hati nurani kami (tubuh kami sebagai pura), seperti halnya anak-anak sapi yang merumput di padang subur, seperti pula seorang gadis di rumahnya sendiri (Titib, 1998: 246).

Badan menjadi tempat sthana dari pramana yang merupakan bagian dari Tuhan Yang Maha Esa. Dengan adanya pramana yang mendiami badan ini, badan menjadi mampu untuk melakukan aktifitasnya. Namun demikian Tuhan Yang Maha Esa merupakan sumber dari pramana maka yang mengakhiri dari kehidupan pramana disetiap badan adalah tuhan Yang Maha Esa pula. Seperti yang terlihat dalam kutipan berikut:

Nimittanira manusa, aturu tan tulus pejah, lunganira hyang pramana, lwir paratra kang sarira, karananira tan matya, hyang antukara ring raga, sopnya no.. Nti mijil ing angga (Dewa ruci, pupuh V pada 18).

Terjemahannya:

Sebabnya orang yang tidur tidak lanjut mati, perginya pramana seakan-akan badan seperti mati, sebabnya tidak mati, karena Tuhan Dia yang mengakhiri hidup masih dalam badan... (Tim Penyusun, 2008:30).

\section{B. Perjalanan Tokoh Bhima Sebagai Bentuk Tirtayatra}

Untuk mendapatkan kesepahaman pengertian dalam hal ini akan disampaikan pengertian dari tirtayatra. Tirtayatra berasal dari dua suku kata yakni tirta dan yatra. Tirta berdasarkan Kamus Bahasa Sansekerta memiliki pengertian seperti pemandian, sungai, kesucian air, toya atau air suci, sungai yang suci atau tempat berziarah. Sedangkan kata yatra memiliki arti perjalanan suci. Dengan demikian dapat dikatakan bahwa tirtayatra adalah perjalanan suci untuk mendapatkan atau memperoleh air suci (Suparta, 2005: 8). Namun demikian, pengertian dari tirtayatra yang terdapat di dalam pengertian masyarakat dapat dipahami dengan kata tangkil atau sembahyang di pura-pura. Sedangkan dalam penelitian ini, pengertian dari tirtayatra lebih merujuk kepada pengertian perjalanan suci untuk mendapatkan air suci, melalui perjalanan yang disertai dengan pengendalian, pengekangan dan penyerahan diri.

Seperti yang telah pernah disinggung di atas, bahwa perjalanan yang dilakukan oleh Bhima merupakan sebuah perjalanan yang suci. Hal ini dapat dilihat dari tugas yang diemban oleh Bhima untuk mencari tirtha amertha pawitra yang merupakan air yang suci. Seperti yang terdapat dalam kutipan berikut:

"Gatya lampahi nararya, pangutusing Dang Hyang Drona, ameta toya pawitra, suci mawenang... lali sireng pa wwang sanak, iba tan ketang denira, lagwa sireng antaka, tan jrih durgama ning pasir" (Dewa Ruci, pupuh I pada 1).

Terjemahannya:

Cepat langkah sang raja putra, sebagai utusan Dang Hyang Drona, untuk mencari air suci, suci jernih, lupa ia pada sanak saudara, ibunya tidak diharaukannya, ia iklas untuk mati, tidak 
takut pada bahaya laut (Tim Penyusun, 2008: 1).

Selain hal tersebut, yang mendukung bahwa perjalanan yang dilakukan oleh Bhima sebagai bentuk dari perjalanan suci atau tirthayatra merujuk pada petikan mantra pada Rg Veda I. 23. 23, sebagai berikut:

Apo adyanv acarisam rasena sam agasmahi Payasvan agna a gahi sam prayaya sam ayusa.

\section{Terjemahanya:}

Sekarang kami menerjunkan diri ke dalam air, kami menyatu dengan kekuatan yang menjadikan air ini. Semoga kesucian yang tersembunyi dalam air ini, menyucikan dan memberikan kekuatan suci kepada kami (Titib,1998: 247).

Berdasarkan petikan mantra $\mathrm{Rg}$ Veda di atas, dapat diketahui bahwa air memiliki sifat menyucikan, Bhima yang menuju ke lautan dan bahkan menceburkan dirinya kelautan sebagai bentuk penyatuan dengan unsur yang menyucikan yang terdapat pada air di lautan. Air yang menyucikan diri Bhima dan memperkuat dirinya sebelum Bhima bertemu dengan Hyang Dewa Ruci. Dengan kata lain, Bhima bertemu dengan Hyang Dewa Ruci dalam keadaan bersih. Hal yang serupa disampaikan Oleh Putra (Wawancara pada tanggal 24 Januari 2018) bahwa naga yang membelit Bhima sebagai gambaran dari keinginan dan hawa nafsu yang mengikat Bhima, namun Bhima berhasil melepaskan ikatan tersebut sehingga Bhima menjadi suci tanpa ikatan dan bersih luar dalam.

\section{Simpulan}

Berdasarkan hasil penelitian yang telah dilakukan mengenai tokoh Bhima dalam Teks Dewa Ruci (Kajian Teologi Hindu), maka dapat ditarik simpulan sebagai berikut: Religiusitas tokoh Bhima dari sudut pandang Teologi Hindu dalam Teks Dewa Ruci dapat diketahui melalui pengendalian diri yang dilakukan oleh Bhima, dan penyerahan diri yang berdasarkan dharma oleh Bhima. Sedangkan religiusitas tokoh Bhima dari sudut pandang teologi Hindu terungkap dengan adanya konsep pramana sebagai asas kehidupan alam semesta dan makhluk hidup serta perjalanan yang dilakukan oleh Bhima merupakan perjalanan suci atau sebagai bentuk tirthayatra.

\section{DAFTAR PUSTAKA}

Admin. 2012. Pengertian Yoga. (Online). (http://niatingsun.blogspot.com/2012/03/ pengertian-yoga.html/, diakses 2 Agustus 2018)

Avadhutika, Anandamitra, Acarya. 2001. Yoga Untuk Kesehatan. Jakarta: Persatuan Ananda Marga Indonesia

Clifford, G. 1980. Kebudayaan dan Agama, terj. Francisco Budi Hardiman, Yogyakarta: Kanisius.

Dunia Fitnes.com. 2012. 4 Manfaat Yoga Bagi Si Super Sibuk. (Online). (http://duniafitnes. com/health/4-manfaat-yoga-bagi-si-supersibuk.html/, diakses 2 Agustus 2018)

Fukuyama, Francis. 1999. Social Capital and Civil Society.The Institute of Public Policy, George Mason University.

Geriya, I Wayan. 2000. Pariwisata \& Dinamika Kebudayaan Lokal, Nasional, Global. Denpasar: Upada Sastra.

Harsawardana, Susan. 2011. Konsep Terapi Yoga. (Online). (http://susanharsawardana. wordpress.com/2011/10/25/konsep-terapiyoga.html/, diakses 2 Agustus 2018)

Hartini, Sri. 2002. Surya Namaskar. Surabaya: Paramita

Prabhat Ranjan Sarkar. 2003. Psikologi Yoga. Jakarta: Persatuan Ananda Marga Indonesia 
Ritzer, George-Douglas J. Goodman. 2007. Teori Sosiologi Modern. Jakarta : Kencana Predana Media Group. Sad Guru Sant Keshavadas (Agus S. Mantik). 2000. Gayatri, Semedhi Mahatinggi, Denpasar:PTPustakaManikgeni Sauri, Sofyan. 2006. Pendidikan Berbahasa Santun. PT genesindo. Bandung

Shangkala.2009.PengertianYoga.(Online).(http:// artshangkala.wordpress.com/2009/10/07/ pengertian-yoga/, diakses 2 Agustus 2018)

Sita, Nadia. 2010. Apakah Arti, Tujuan, dan Manfaat Yoga. (Online). (http://sitaaerobic. blogspot.com/2010/03/apakah-arti-tujuandan-manfaat-yoga.html/, diakses 2 Agustus 2018)

Swami Niranjanananda Saraswati. 2006. Yoga and Expansion of Consciousness. Colombia: The National University

Svami Satya Prakas Saraswati. 2002. Patanjali Raja Yoga. Surabaya: Paramita. 